\title{
«ІДЕАЛЬНА МОВА» ЯК ЛІНГВО-ФІЛОСОФСЬКИЙ ФЕНОМЕН
}

\author{
Н.С. Кудрявцева
} Межі моєї мови означають межі
мого світу.

Л. Вітгенштейн

\section{1 Передісторія}

Концепція «ідеальної» або «універсальної мови» походить 3 наскрізної для всієї філософії мови та лінгвістики ідеї «двох мов». Згідно з цією ідеєю, людська мова складається з двох шарів, або двох окремих мов, однією з яких люди говорять про сутності, а іншою - про явища. Перша мова чітка, однозначна, впорядкована та спільна для всіх людей; друга являє себе в багатоманітності національних мов - мінливих, непослідовних, багатозначних.

Як зазначає Ю. Степанов, вперше ця думка ясно з'являється в рукописах одного з граматистів схоластичного періоду Боеція Дакійського, який близько 1270 р. почав розглядати граматику як науку, декларуючи їі спільність для всіх мов [8, с. 108]. Основою цієї спільності могла бути лише логіка, про що висловився і Роджер Бекон, вперше використавши термін «універсальна граматика» (див.: [8, с. 108]).

Проте в повному вигляді ідея «двох мов» проявляється тільки в XVI ст., коли в мовному середовищі тогочасної Європи існують і використовуються (часто одними й тими самими людьми) одночасно гуманістична, тобто близька до класичної, латина, народна латина широко-

Актуальні проблеми духовності: 
го вжитку та національні мови. На тлі такого мовного різнобарв'я виникає оригінальна лінгвістична концепція іспанського гуманіста Франсіско Санчеса, викладена в його головній праці «Мінерва, або про причини латинської мови» (див.: [5]).

Згідно з думкою Санчеса, аналізуючи речення і частини мови, цілком можливо виявити певні універсальні засади мови взагалі, тобто засади «універсальної мови» (див.: [8, с. 145]). Двозначність та неясність речень конкретних мов обумовлена додаванням чогось зайвого, що перешкоджає чіткому виразу думки, а також скороченням або виключенням чогось, що обов'язково присутнє в логічно складеному реченні. Останню з описаних особливостей речень конкретних мов Санчес називає еліпсисом. На його думку, найближчою до універсальної, логічно впорядкованої, мови є латина, подібна до класичної латини Риму і покликана служити насамперед завданням науки.

Механістична картина світу, яка для свого опису потребувала чіткої, звільненої від двозначностей мови, сприяла розвитку концепції «універсальної мови» в XVII ст., позначеному появою праць зі штучних, формалізованих мов, розпочатих Рене Декартом і продовжених Готфрідом Лейбніцем.

Декартові міркування про мову безпосереднім чином викладені лише в його листі до абата Мерсенна від 20 листопада 1629 року [13]. За Декартом, сутність універсальної мови становить специфічна граматика, позбавлена дефективних відмін та дієвідмін, що дозволить будьякій людині оволодіти такою мовою за порівняно невеликий проміжок часу [13, с.3]. Однак найбільше Декарта вабила думка про створення фiлософсъкої мови, в якій усі слова було б впорядковано подібно до того як впорядковані числа. Порядок слів філософської мови достеменно відображав би порядок, в якому знаходяться всі думки, які тільки можуть виникнути в людській голові. Якби хто-небудь зміг виділити ті прості ідеї, що знаходяться в людському мисленні і з яких складається все те, про що люди думають, відразу ж з'явилася б спільна, універсальна мова, яка б дозволила розуму сприймати речі в такому чіткому вигляді, що помилятися для нього було б практично неможливо $[13$, с.6]. Слова конкретних мов, навпаки, багатозначні, через що люди майже нічого не розуміють так як слід. Декарт був упевнений в можливості створення такої філософської мови і відкритті специфічної науки, від якої вона залежить.

Ця Декартова ідея привернула увагу Лейбніца, що знайшло своє відображення в змісті його «Нових дослідів про людське розуміння. . . [3], де окрема книга присвячена проблемам мови. Лейбніц здійснив 
семантичний аналіз сотень загальновживаних слів та філософських термінів із латинської мови. За допомогою такого аналізу філософ намагався дійти певної нечисленної кількості невизначуваних термінів, котрі і позначали б ті прості ідеї, про які писав Декарт. У своїх «Таблицях дефініцій» Лейбніц навів зокрема такі основні філософські поняття: «Сутність», «Існуюче», «Абстрактне», «Конкретне», «Акциденція», «Тіло». Він відзначив, що терміни, як власне і загальновживані слова, можуть бути згруповані в певні семантичні поля, які дають можливість виявити спільне для них значення, таким чином певною мірою передбачивши розвиток компонентного аналізу в лінгвістиці XX ст. В «Раціональній мові» Лейбніц так само, як Декарт, звернув увагу на граматику, зазначаючи, що правильні граматики всіх мов $\epsilon$ лише частинами філософської граматики, перевагу серед яких має граматика латинської мови. Створення раціональної мови має здійснюватися через переклад того чи іншого речення з латини шляхом «парафрази», тобто встановлення такої його версії, яка була б позбавлена будь-яких аномальних граматичних явищ $[4$, с. 422$]$.

Парадигма «двох мов» набуває чіткого оформлення у філософії мови французьких просвітників, які у своїй великій «Енциклопедії» висловлюють думку про існування «загальної» та «окремої» граматик. Загальна граматика вивчає принципи мовної побудови, притаманні всім без винятку мовам, а її закони, вічні та універсальні, визначають сферу можливого і лише передбачають можливість виникнення конкретних мов. Окремі граматики, навпаки, характеризуються вільно прийнятими й мінливими принципами та законами, що діють доти, доки їх носії не вирішать модифікувати їх за взаємною згодою. В «Енциклопедії» також наведено двоярусну термінологію відповідно до загального та етнічного (рівня окремих граматик) рівнів мови. Так, до загального рівня належать синтаксис, пропозиція, терм, а до етнічного - конструкція, фраза, слово (див.: [8, с. 118]).

Отже, ідея «універсальної мови» 3 часів свого виникнення і до кінця XVIII ст. існувала переважно як об'єкт філософської рефлексії, а теорії «універсальної мови» входили до загальнофілософських систем ïх авторів - визначних представників світової філософії. Це пов'язано 3 тим, що від Платона і аж до Гумбольдта теорії мови не поділялися на філософію мови та лінгвістику. Лінгвістика не відокремлювалася від логіки, і її предмет становили єдині загальнолюдські способи вираження думки. 3 початком XIX ст. лінгвістика отримує незалежний статус як наука про різноманітні мови в їх історичному розвитку, а концепція «універсальної» мови відтворюється не тільки на філософському, а й 
на суто лінгвістичному грунті.

\section{2 «Ідеальна мова» як предмет філософського до- слідження}

Філософський аспект феномену «ідеальної мови» пов'язаний насамперед з проблемою співвідношення свідомості, тобто мовленнєвого мислення, та об'єктивної дійсності. Коли Декарт сформулював своє дуалістичне уявлення про сутнісне відокремлення свідомості від тіла, однією з головних тем новочасної епістемології став репрезентаціонізм. Згідно з цим принципом, ментальні об'єкти репрезентують речі зовнішнього по відношенню до свідомості світу, а мислення передбачає оперування цими репрезентантами. Відповідно, аналіз проблеми відношення мови до зовнішнього світу набув «логічної» спрямованості і походив з припущення про те, що знання, виражене засобами мови, $є$ знанням про зовнішній світ, трансцендентним стосовно цього знання і мови. При цьому елементи мови вважаються аналогами елементів свідомості, яка судить про зовнішній світ, а власне мова розглядається з точки зору їі функціонування як задана і незмінна система засобів формування й вираження думки.

Така мова може бути визнана ідеальною за умови, якщо вона здатна адекватно відображати структуру об'єктивно існуючого світу. Якщо уявити світ не як множину речей, що знаходяться в деякому порожньому просторі, а як такий, що утворюється певною сукупністю фактів, можна припустити, що речення ідеальної мови мають адекватно репрезентувати структуру кожного окремого факту. Як стверджує одне з вихідних положень «Логіко-філософського трактату» Людвіга Вітгенштейна: «Світ є сукупність фактів, а не речей» [18, 1.1]. Цю тезу повністю сприймає Бертран Рассел, який кладе їі в основу своєї «Філософії логічного атомізму» [17]. Мовною формою для вираження того чи іншого факту є речення, або висловлювання [17, с. 187].

Уявлення про світ не як про певну множину окремих речей, а як про ситуації, в яких речі знаходяться в певних взаємовідносинах, зумовлює специфічну картину мови. Якщо окремі речі не є компонентами світу, то і мова не може уявлятися як така, що складається зі слів, які є назвами окремих речей. Для того, щоб виявити компоненти мови, необхідно усвідомити, що являє собою факт як компонент світу. Згідно з Расселом (тут він знову приєднується до думки Вітгенштейна - див.: [18, 2]), факт є все те, що має місце у Всесвіті. Факт може 
бути визначений лише наочно і являє собою певний очевидний стан речей у світі. Крім того, факт є те, що зумовлює істинність або хибність будь-яких тверджень. Якщо погодитись з думкою Вітгенштейна і Рacсела, що описом факту є речення-висловлювання, то можна зробити висновок, що основними структуроутворюючими компонентами мови виступають речення.

Отже, на передній план у мові виходять не назви окремих речей, тобто імена, а відносини між цими іменами, відображення яких мовними засобами дає змогу створити речення. А якщо йдеться про речення, то в центрі уваги опиняється синтаксис. Синтактичний підхід до розгляду мови фокусується на відносинах між іменами - назвами окремих речей. Цим відносинам в реченні відповідають предикати, які, на відміну від імен, не можуть іменувати будь-що поза мовою. В «Проблемах філософії» Рассел доволі чітко визначив контури поняття «предикат». Навівши як приклад речення «Я в своїй кімнаті», він вказує на те, що не можна стверджувати, що «я», «моя кімната» $\mathrm{i}$ «в» існують в однаковому сенсі. «Я» і «моя кімната» справді існують (і є речами об'єктивного світу, які в мові отримують імена), проте навряд чи те саме можна сказати про «в». При цьому в даному реченні «в» безперечно і $є$ саме тим, що дозволяє описати зображену ситуацію, визначаючи в яких саме відносинах знаходяться «я» $\mathrm{i}$ «моя кімната» $[16$, с.90]. Отож, предикати позначають не окремі речі, що можуть бути названі іменниками, а певні відносини і якості. Так, ми приходимо до висновку, що складовими частинами речення як мінімального компоненту мови є предикати та імена ${ }^{1}$.

Таким чином, стає можливим говорити про більш конкретні вимоги, яким має відповідати ідеальна мова. По-перше, і тут не можна не погодитися з Декартом, імена ідеальної мови мають бути однозначними, кожне ім'я має називати лише одну окрему річ, мати чітко закріплене значення. 3 цього випливає недоречність в ідеальній мові таких лінгвістичних явищ як синонімія, омонімія, полісемія і т. п., які в природних мовах нерідко виступають причинами непорозумінь та помилок. По-друге, і це наразі є ключовою вимогою, синтаксис ідеальної мови має бути влаштований у такий спосіб, аби завжди надавати можливість знайти такий предикат, який адекватно відображав би відно-

\footnotetext{
${ }^{1}$ Слід згадати про значний вплив на цю концепцію Рассела функціонального підходу до аналізу мови, розвинутого Готлобом Фреге у [14] і особливо у [15]. За Фреге, головними категоріями мовних висловлювань $є$ імена та функціональні вирази; імена позначають окремі предмети, а функціональні вирази репрезентують певні (функціональні) взаємозалежності між ними.
} 
сини між речами в структурі факту. Як зазначає Людвіг Вітгенштейн, для того щоб речення стверджувало факт, має бути дещо спільне між структурою речення і структурою факту $[18,2.02-2.225]$. Таким чином, синтаксис ідеальної мови від самого початку запобігатиме будьяким логічним помилкам.

Звідси походить не тільки важливий висновок про те, що знання, виражене засобами ідеальної мови, завжди буде істинним; в цих вимогах розкривається власне мета створення ідеальної мови-адекватне відображення структури об'єктивної дійсності. На думку Г. Бергмана, побудова ідеальної мови $є$ належним способом репрезентації структури нашого світу; адже структура такої мови в певному сенсі являе собою «картину» структури світу [11, с. 132$]$.

Якщо головною функцією ідеальної мови є функція репрезентації, а не функція засобу комунікації між людьми, очевидним стає той факт, що такою мовою навряд чи можливо буде розмовляти. Тут можна погодитися з Г. Бергманом, що ідеальна мова буде скоріше «проектом» (blue print) або «схемою», довершеною в тому сенсі, що вона в принципі повинна демонструвати (show) структуру і схематичне улаштування всіх основних сфер нашого досвіду [11, с.134].

Хоча ідеальною мовою і неможливо розмовляти, це зовсім не означає, що ми не можемо уявити, який вона могла б мати вигляд. Пам'ятаючи, що така мова має бути універсальною, а тому необмеженою рамками певної етнолінгвістичної картини світу, ідеальну мову можна сконструювати лише у спосіб подібний до математичного числення, яке $є$ універсальним і однаково зрозумілим будь-якій людині. Неважко уявити собі таку мову у вигляді системи умовних позначень, що використовуються в сучасній логіці: індивідні константи та змінні, предикатні константи та змінні, оператори, квантори, пропозиційні зв'язки, дужки. Таким чином, як зазначав Рудольф Карнап, під «логічним синтаксисом» мови розуміється система формальних правил цієї мови, а також наслідків цих правил $[12$, с. 56]. Існує два види таких правил: правила утворення (Formregeln), які регулюють створення речень-висловлювань із вихідних символів (наприклад, слів), та правила перетворення (Unformungsregeln), що вказують, у який спосіб з даних речень-висловлювань можуть бути виведені нові, більш складні за структурою висловлювання. Таким чином, абстрагуючись від значень окремих слів та речень, але не заперечуючи їх, створення й трансформування пропозицій можна уподібнити грі у шахи: так само, як шахові фігури, слова можна об'єднувати і маніпулювати ними відповідно до певних правил. Це, на думу Карнапа, також можна ви- 
разити тим положенням, що мова розглядається як числення [12, с. 57].

Призначення «логічного синтаксису» Карнап вбачав у тому, що він має слугувати за формальну структурну теорію мови науки. Проголосивши свою програму подолання метафізики логічним аналізом мови, він встановив критерії відокремлення осмислених речень від безглуздих, що, за його переконанням, мало звільнити філософію від метафізичних спекуляцій і надати їй статус логіки науки. Причиною виникнення безглуздих речень метафізики, або псевдоречень, є, на думку Карнапа, невідповідність граматичного синтаксису природних мов вимогам логічного синтаксису [1, с. 17]. Недоліком природних мов слід вважати те, що вони, на противагу логічно правильній мові, допускають однакові форми для осмислених і безглуздих поєднань слів. Так, засобами історико-граматичного синтаксису природних мов на питання «Як на вулиці?» можливо сформулювати два варіанти подібних за формою відповідей, одна з яких, проте, виявляється безглуздою з точки зору «логічного синтаксису»: 1) «На вулиці дощ»; 2) «На вулиці ніщо». Логічно коректною формою для відповіді 2) є 3) «Не існує нічого, що є на вулиці». В той час, як граматичний синтаксис форми 2) дозволяє подальше продукування безглуздих речень типу «Ми знаємо ніщо», «Ніщо ніщить» по аналогії з «Ми знаємо дощ» і «Дощ дощить», в логічно коректній мові подібні форми взагалі не можуть бути створені [1, с.19]. Таким чином, в логічно вірно побудованій мові речення метафізики взагалі неможливо було б сформулювати.

Карнапівська парадигма «логічного синтаксису», протиставленого історико-граматичному синтаксису природних мов, являє собою наступний етап розвитку згаданої вище ідеї «двох мов», одна з яких логічна, впорядкована і спільна для всіх, а інша - національна, своєрідна, окрема для кожного народу [8, с.166]. I хоча позбутися «вічних» питань метафізики, так само, як і встановити відношення свідомості до об'єктивної дійсності, через конструювання «логічного синтаксису» так і не вдалося, спроба формалізації природних мов, здійснена Расселом, Вітгенштейном та Карнапом на шляху пошуку «ідеальної мови», засвідчила і позитивні наслідки. Формалізовані мови, які вивчаються сучасною логікою і математикою, являють собою формальні структури реально існуючих або можливих мов, що в свою чергу відображає важливі риси мови в повсякденному вжитку. Свідоме абстрагування формальної логіки від інших властивостей мови і від того, як вона змінюється, допомогло виявити особливий предмет дослідження - мовну структуру як таку [6, с.53]. Загалом же «раціональне зерно» мовних концепцій Рассела, Вітгенштейна та Карнапа, на нашу думку, полягає 
в тому, що вони вперше привернули увагу до відносин між речами в структурі факту, що в свою чергу дозволило уточнити поняття предикату. В подальшому це спричинило виникнення ідеї загального зв'язку «фактів» у світі та зв'язку «висловлювань»у мові.

\section{3 Ідеалізація мови в лінгвістиці}

У другій половині XX ст. деякі американські лінгвісти під впливом внутрішніх потреб своїх досліджень також звернулись до філософських ідей Декарта щодо мови. Ці ідеї, як було висвітлено вище, до певної міри стали джерелом логіко-філософських концепцій побудови «ідеальної мови» в аналітичній філософії, а в лінгвістиці сприяли не тільки постановці подібного завдання, а й взагалі початку нової епохи в науці про мову - виникненню генеративної лінгвістики.

Засновником генеративної лінгвістики як однієї з галузей формального напрямку в мовознавстві є Ноам Хомський (Chomsky), який вперше виклав свої ідеї у загальновідомій праці під назвою «Синтаксичні структури» (1957). Головною одиницею мови Хомський визначив речення, а не фонему чи морфему. Проголосивши разом з тим пріоритет дедуктивного підходу до вивчення мови над індуктивним, Хомський формулює свою граматику за зразком дедуктивно-аксіоматичних принципів побудови логічних числень. В «Аспектах теорії синтаксису» (1965) [10] Хомський виклав концепцію так званої «породжувальної граматики», яка втілює певний механізм, що породжує всі граматично правильні послідовності мови згідно з певними правилами. У такий спосіб Хомський розвинув ідею про творчий характер мови, згідно з якою людина здатна породжувати цілком нові речення й розуміти речення, яких ніколи не чула раніше.

Подібна лінгвістична перспектива, прийнята генеративною граматикою, вочевидь, єднає її з вище зазначеними настановами «логічного синтаксису» Карнапа; однак, на нашу думку, особливої уваги наразі заслуговує концепція «глибинної структури» (deep structure), яка 3 першої половини 60-х рр. стає одним 3 найважливіших компонентів генеративної теорії Хомського. Існування глибинних та поверхневих структур виявили ще у 1660 р. автори граматики Пор-Рояля - Антуан Арно і Клод Лансло, яких Хомський вважав своїми попередниками. Згідно з його точкою зору, «глибинна структура», являє собою розумове утворення, пов'язане трансформаційними переходами з поверхневою структурою, яка набуває звукового оформлення. Глибинна 
структура, на противагу поверхневій, виступає як дозвукове, а значить і дословесне утворення, а система правил, відповідно до яких розумові утворення пов'язуються зі звуковими, і становить, за Хомським, граматику. Проте, ілюструючи поняття глибинної структури, Хомський представляє останню як відношення між цілком реальними словами. Наводячи як приклад речення A wise man is honest («Myдра людина чесна»), він зазначає, що суб'єктом цього речення $\epsilon$ a wise man, a предикатом is honest. Однак, глибинна структура буде дещо інша, адже в основі складної ідеї a wise man, яка є суб'єктом речення, знаходиться судження з суб'єктом man «людина» і предикатом be wise «бути мудрим». Таким чином, поверхневому словосполученню a wise man «мудра людина» відповідає глибинна структура a man is wise «людина є мудрою» $[7$, с. 16].

На наш погляд, в даному випадку слід звернути увагу саме на те, що «глибинна структура» Хомського, визначена як «дословесна», очевидно, має логічну природу. Ця логічна ознака «глибинної структури» зумовлена нічим іншим, як висвітленням тих специфічних відносин між іменами, які позначаються предикатами. В такому разі можна припустити, що поняття дословесної «глибинної структури», розроблене Хомським, виступає лінгвістичним аналогом логіко-філософської концепції «ідеальної мови» як «схеми», котра відображає особливості впорядкування оточуючого нас світу, з тією різницею, що конструкція Хомського, також в певному розумінні будучи «схемою», стосується лише мови.

Слід зауважити, що генеративну лінгвістику Хомського спіткала доля, в дечому подібна до долі конструктивістських концепцій вище згаданих представників логічного позитивізму: в той час як основні настанови генеративістів було піддано нищівній критиці (хоча розробка нових ідей на основі загальної генеративістської орієнтації продовжується донині), велика кількість їх інших положень набула вагомого значення для прикладної лінгвістики в цілому. Як відзначає І. Сусов [9], Хомський виступив ініціатором революційного повороту спочатку в американський, а згодом і у світовій лінгвістиці, до динамічного (на противагу статичному) розгляду мови з урахуванням даних когнітивної психології. Саме ним було висунуто ідеї про вродженість мови, а також про різницю між лінгвістичною компетенцією і вживанням. Безперечним $є$ вплив ідей Хомського на розробку більш точних методів лінгвістичного дослідження, на зародження та бурхливий розвиток синтаксичної семантики як в США, так і в країнах Європи. 


\section{4 Універсальна мова та універсальна писемність}

Хоча концепція створення «ідеальної» мови ані у філософському аспекті - як адекватного засобу репрезентації структури об'єктивного світу, ані у лінгвістичному розумінні - як спільного засобу людської комунікації, (поки що) не була успішно реалізована, ідея «двох мов», 3 якої вона походить, була і залишається невід'ємним компонентом різноманітних лінгво-філософських досліджень, являючи собою за висловом Ю. Степанова одну 3 «філософських констант мови» [8, с.7]. Неможливо, на нашу думку, заперечувати актуальність подальших досліджень у напрямку лінгво-філософського конструювання також 3 огляду на те, що вже сьогодні в різних галузях з успіхом використовується декілька метамов, які засновуються на принципах універсальної писемності. Це насамперед мова математики та математичної логіки, мови інших прикладних символічних систем (фізика, хімія, картографія і т. п.), і нарешті піктографічна мова знаків дорожнього руху. Звичайно, універсальна писемність ще не є універсальною мовою, проте досвід Китаю та Японії з їх численними діалектами, засвідчує ефективність єдиної ієрогліфічної системи як засобу проти значних фонетичних розбіжностей.

Слід також відзначити, що Декартові міркування про мову сприяли не тільки розвитку логіко-філософського конструктивізму та генеративної граматики. 3 його ім'ям пов'язане і виникнення інтерлінгвістики як науки про штучні мови. Декартова ідея штучної універсальної формалізованої мови, а також висунуті ним принципи філософського лінгвопроектування стали спільною основою всіх подальших версій апріорних штучних мов. В свою чергу Лейбніц в дисертації «Про комбінаторне мистецтво» (1666) виклав ідею пазиграфії, згідно з якою слова, тобто символи пазиграфії, повинні не тільки виражати ідеї, а й утворювати взаємозв'язки (синтаксис). Продовжувачі його «справи» - Дж. Дальграно, Дж. Уілкінс, Ж. Кондорсе, Е. Кондільяк та ін. - займалися конструюванням писемності, символи якої являють собою не слова, а поняття [2, с. 555].

Додамо, що проект побудови штучної універсальної мови, викладений Декартом в його листі абату Мерсенну (1629) [13], було майже буквально реалізовано доктором Людвігом Заменгофом у 1887 р. Запропонована ним інтернаціональна мова «Есперанто», як і інші штучні мови, спирається на принципи однозначності та одновиразності, відповідно до яких один вираз може мати тільки одне значення, і одне значення може приписуватися лише одному виразу. Більшість слів 
есперанто побудовано на основі кореней, запозичених з романських та германських мов, а граматика налічує всього шістнадцять правил, 3 яких немає винятків. Загалом було створено близько 600 проектів штучних мов, найпоширенішими з яких є есперанто, «волапюк» (1890) (перша загальновизнана міжнародна мова, запропонована німецьким пастором І. Шлейером), та «ідо» (1907) (прямий нащадок та суперник есперанто, створений французькими лінгвістами Л. Бонфором та Л. Кутюра).

Цікаво, що в ХХ ст. створення пазиграфій стало захопленням виключно авторів художніх творів, найвідомішим з яких в цьому сенсі $є$, напевно, Джон Р.Р. Толкін. Англійський письменник, який до того ж був лінгвістом та оксфордським професором англосаксонської мови, є творцем декількох штучних мов, якими розмовляють персонажі таких його відомих книг, як «Хобіт» та «Володар перснів». Толкін володів кількома десятками мов, а свої власні створював, керуючись виключно красою звучання.

Безперечно, від існуючих універсальних кодів до створення універсальної мови як такої залишається ще значно більше, ніж один крок. Імовірно, про реальну універсальну писемність, а тим більше про спільну мову, можна буде говорити лише тоді, коли з'явиться спільна для всього людства система ідей, або знаків, значення яких не змінюватиметься залежно від місцевості, країни, нації. Наразі ж ідеалізація мови, за принципами логіко-філософського підходу, дозволяє уявити структури формальних мов більш виразно, ніж це є досяжним для лінгвістів, які досліджують виключно складні природні мови. В той самий час результати аналізу, проведеного логікою, не можна буквально застосовувати до емпірично наданих природних мов. Концепція «ідеальної мови» в такому разі функціонує подібно до того, як у фізиці використовуються поняття ідеального газу, ідеальної рідини, руху за відсутністю тертя, тощо. Таким чином, йдеться про певні ідеалізовані об'єкти, для яких можна встановити прості закони, котрі значно сприяють розумінню того, що відбувається в дійсності, і що, напевно, залишилося б невідомим, якщо б цю дійсність було піддано лише безпосередньому розгляду на рівні буденної інтуӥції. Саме про таке призначення концепції «ідеальної мови», на нашу думку, свідчить різноманіття вищезгаданих досягнень - наслідків застосування цієї конструкції в лінгвістиці. Питання ж побудови «ідеальної мови» як універсального засобу людської комунікації залишається відкритим, і неможливо навіть припустити, коли воно отримає чітку і однозначну відповідь. 


\section{5 Бібліог рафія}

[1] Карнап P. Преодоление метафизики логическим анализом языка // Вестник Московского университета. Сер. 7, Философия. 1993. - № 6. - C. 11-26.

[2] Королев K. Универсальный язык и универсальная письменность: в погоне за мечтой // Языки как образ мира. - М.: ООО «Издательство АСТ», 2003. - C. 549-565.

[3] Лейбнии Г. Сочинения в 4-х т. Т. 2 / Ред., авт., вступ. статьи и примеч. И.С. Нарский. - М.: Мысль, 1983. - С. 274-362.

[4] Лейбнии Г. Рациональный язык // Соч-я в 4-х т. Т. 3 / Ред., авт., вступ. статьи и примеч. И.С. Нарский. - М.: Мысль, 1983. C. 422-424.

[5] Малявина Л.А. У истоков языкознания Нового времени (Универсальная грамматика Ф.Санчеса «Минерва» 1587 г.). М.: Наука, 1985.

[6] Моррис Ч. Основания теории знаков // Семиотика (сб. переводов). - М.: Радуга, 1983. - С. 37-89.

[7] Солнцев B.M. Относительно концепции «глубинной структуры» // Вопросы языкознания. - 1976. - № 5. - С. 13-25.

[8] Степанов Ю.С. В трехмерном пространстве языка.- М.: Наука, 1985.

[9] Сусов И.П. История языкознания. Учебное пособие для студентов старших курсов и аспирантов.-Тверь: Тверской гос. ун-т, 1999.-[Электронный ресурс]. Режим доступа: http://www.classes.ru/grammar/141.susov/

[10] Хомский Н. Аспекты теории синтаксиса. - М.: Наука, 1972.

[11] Bergmann G. Two Criteria for an Ideal Language // The Linguistic Turn / Ed. by Richard M. Rorty. - Chicago: The University of Chicago Press, 1992. - P. 132-134.

[12] Carnap R. On the Character of Philosophical Problems // The Linguistic Turn / Ed. by Richard M. Rorty. - Chicago: The University of Chicago Press, 1992. - P. 54-62. 
[13] Descartes to Mersenne, 20 November 1629 // Descartes: Philosophical Letters, translated and edited by Anthony Kenny.-Oxford: Clarendon Press, 1970. - P.3-6

[14] Frege, G., Function und Begriff. Vortrag, gehalten in der Sitzung vom 9. Januar 1891 der Jenaischen Gesellschaft für Medizin und Naturwissenschaft. H. Pohle, Jena. - 1891.

[15] Frege, G. Über Sinn und Bedeutung // Zeitschrift für Philosophie und philosophische Kritik. - 100. - 1892. - S. 25-50.

[16] Russell B. The Problems of Philosophy. - Oxford: Oxford University Press, New York - Oxford, 1997.

[17] Russell B. The Philosophy of Logical Atomism // Logic and Knowledge: Essays, 1901-1950, Routledge: London and New York, 1992.

[18] Wittgenstein L. Tractatus Logico-Philosophicus. - London: Routledge \& Kegan Paul, 1988. 